\title{
EFFECT OF ENVIRONMENTAL FACTORS, DIFFERENT FORMS OF CARBON, INORGANIC AND ORGANIC FORM OF NITROGENOUS COMPOUNDS ON MYCELIAL GROWTH OF Alternaria alternata ISOLATED FROM INFECTED FRUIT OF BOTTLE GOURD (Lagenaria siceraria (Molina)st.)
}

\author{
ARCHITA PRAKASH ${ }^{\text {al }}$ AND PREETI PRASAD ${ }^{\mathrm{b}}$ \\ ${ }^{a}$ Department of Botany ,Bhoot Nath Degree College, Baghan, West-Champaran, Bihar, India \\ Former Head, Department of Botany, Plant Pathology Laboratory, B.R. Ambedkar Bihar University, Muzaffarpur, Bihar, India
}

\begin{abstract}
Alternaria alternata was isolated from the infected fruit of bottle gourd (Lagenaria siceraria) and pure culture was maintained in the laboratory. In vitro impact of different environmental factors, sources of carbon, inorganic and organic nitrogenous compound, was observed on mycelial growth, as determined by the radial growth on solid culture medium, while the dry mycelial weight in the same culture broth. The study was undertaken to assess mycelial growth of the fungus under different environmental conditions such as pH \& temperature as well as under different nutritional conditions such as carbon and nitrogen sources. Ten different $\mathrm{pH}$ and seven different temperatures were used in which the fungus was cultured. Likewise, nine different carbon sources and six inorganic and eight organic sources of nitrogen compounds were tested. Among the pH, 6.5was found more favorable where the dry mycelial weight was the maximum, $695.75 \mathrm{mg} / 100 \mathrm{ml}$ of culture, while the radial growth was 84.66 $\mathrm{mm}$, followed by $6.0 \mathrm{pH}$, where the dry mycelial weight was 672.56 and radial growth 72.85 . At both pH 3.0 and 8.0, both the dry mycelial weight and the radial growth were the lowest. Highest dry mycelial weight, $688.72 \mathrm{mg} / 100 \mathrm{ml}$ and radial growth 78.48 were noted at $28^{\circ} \mathrm{C}$, followed by $626.28 \mathrm{mg} / 100 \mathrm{ml}$, dry mycelial weight and $68.34 \mathrm{~mm}$ radial growth at $32^{\circ} \mathrm{C}$. Among the carbon sources tested, glucose promoted maximum dry mycelial weight $(680.18 \mathrm{mg} / 100 \mathrm{ml})$, while the radial growth was $82.32 \mathrm{~mm}$, followed by fructose, $672.84 \mathrm{mg} / 100 \mathrm{ml}$ dry mycelial weight and $76.28 \mathrm{~mm}$ radial growth. These values were significantly superior over all the carbon sucrose evaluated followed by sucrose $(628.88 \mathrm{mg} / 100 \mathrm{ml})$ and $72.56 \mathrm{~mm}$ as control. Among the nitrogen sources alanine induced maximum dry mycelial weight $(682.32 \mathrm{mg} / 100 \mathrm{ml})$ and $82.38 \mathrm{~mm}$ radial growth, followed by potassium nitrate $(678.24 \mathrm{mg} / 100 \mathrm{ml})$ and $78.15 \mathrm{~mm}$ radial growth. Minimum dry mycelial weight 422.38 and radial growth $46.26 \mathrm{~mm}$ were obtained in case of p-amino benzoic acid. Among the inorganic sources Aluminum nitrate promoted the minimum $(538.18 \mathrm{mg} / 100 \mathrm{ml})$ and 60.72 radial growths.
\end{abstract}

KEYWORDS: Bottle gourd, Radial growth, Dry mycelial weight, In-organic nitrogen sources, p-aminobenzoic acid, Alternaria alternata

Bottle gourd is an important vegetable for the common people. Both winter and summer crops are being grown at commercial scale. However, summer crops are being damaged by different pathogens. This causes heavy loss to the farmers. From the infected fruits Alternaria alternata was isolated. Experiments were performed to observe the impact of different $\mathrm{pH}$, and temperatures, various carbon and inorganic and organic sources of nitrogenous sources in vitro. From the survey of literature it was found that different workers have done experiments to evaluate the effects of above parameters on different fungal pathogen, as well as on Alternaria species too. Some of them may be mentioned here. Lilly and Barnnet (1951), Bais et al., (1970) on Curvularia pallescens, Hasiza (1970) with Alternaria spp., Verma (1970), on three pathogenic fungi, Reddy (1971) on Species of Helminthosporium; Goyal, (1977) on Alternaria tenuis; Mathur and Sarboy
(1977) with $A$. alternata; Mahapatra et al., (1977); with $A$. sesame; Rawla and Tondon (1977); Gomawat and Ghos (1980); Bharti et al., (2007); in case of Metarhizium spp., Prathibha et al., (2008); Pose et al., (2009); Bhale (2010); Thawre et al., (2010); Dange (2012); Mishra and Mishra (2012); Mehta et al., (2012); Bist (2013); Devi et al., (2014); Dhal et al., (2014); Itoo et al., (2014); Koley and Mahapatra (2015); Hashan et al., (2015); Shilpa et al., (2015); Gawai and Mangnalikar (2018). To determine the most readily utilizable source of carbon, nitrogen and most suitable $\mathrm{pH}$, and temperature by the fungus, in vitro, the present study was undertaken.

\section{MATERIALS AND METHODS}

In the present study Richard's Medium was used for the study and different parameters as mentioned above were tested. 


\section{Different Ranges of pH}

The $\mathrm{pH}$ of the medium was adjusted between 3.0 to 8.0 using $0.1 \mathrm{NHCl}$ and $0.1 \mathrm{~N} \mathrm{NaOH}$, with the help of digital $\mathrm{pH}$ meter. Here for the determination of dry mycelial weights as an indicator of growth, at different $\mathrm{pH}$, liquid medium was used. After adjustment of the $\mathrm{pH}$, each culture flask was inoculated with $8 \mathrm{~mm}$ culture disc, taken from actively growing peripheral region of the fungus in Petri Plates. The culture disc was taken with the help of presterilized Cork-borer under aseptic condition. The flasks were incubated at $28^{\circ} \mathrm{C}$ in the shaker incubator and mycelial mats were harvested from 10 days old culture.

Similarly, the culture flasks having liquid culture medium were inoculated as described above. However, here the flasks were cultured at $16^{\circ} \mathrm{C}, 20^{\circ} \mathrm{C}, 24^{\circ} \mathrm{C}, 28^{\circ} \mathrm{C}, 32^{\circ} \mathrm{C}$, $36^{\circ} \mathrm{C}$ and $40^{\circ} \mathrm{C}$ separately in the shaker incubator. Harvesting was done after 10 days of incubation.

\section{Carbon Sources}

To determine the most readily utilizable source of carbon, by the test organism, Alternaria alternata the original carbon source of Richard's medium was replaced by other form of carbon. Quantity of each carbon composition was determined on the basis of their molecular weight so as to provide equivalent amount of carbon as that of sucrose present in the basal medium. The carbon sources used were glucose, galactose, mannose, fructose, xylulose, mannitol, lactose, maltose, raffinose, and sucrose was used as control. $30 \mathrm{ml}$ of each medium was taken in $100 \mathrm{ml}$ flask. After sterilization inoculation was done as described above.

\section{Nitrogen Sources}

Potassium nitrate in the basal medium was replaced by equal amount of different inorganic organic sources of nitrogen. This was done by calculating the amount of nitrogen in each compound. Here also Richard's agar medium was used for radial growth while the broth for dry mycelial weight. From the broth the mycelial mat was collected on pre-sterilized and weighed, Whatman filter paper No.-42.

The mycelial mat was washed with hot water with the help of jet pipette to remove traces of culture medium. Mycelial mat from $250 \mathrm{ml}$ of cultures were collected together and placed in hot air incubator adjusted at $50^{\circ} \mathrm{C}$.
Weight was taken and it was again dried. This was repeated till the constant weight was obtained. Each experiment was performed in triplicate and each time 15 culture flasks were used. The mean of the data was tabulated in the form of tables for analysis and discussion. They are represented by the graph from 1 to 5 .

\section{RESULTS}

From the graph 1 it was clear that highest dry mycelial weight $695.75 \mathrm{mg} / 100 \mathrm{ml}$ of culture was obtained at $\mathrm{pH} 6.5$, followed by $672.56 \mathrm{mg}$ at $\mathrm{pH} 6.0$. It was further noted that the test organism that was Alternaria alternata could grow in wide range of $\mathrm{pH}$ i.e., from 3.0 to 8.0 in above experiments. However, the rate of growth was influenced by the lowest as well as the highest $\mathrm{pH}$ that was 3.0 and 8.0, respectively. Due to this at this $\mathrm{pH}$ the poor growth of the fungus was recorded. The radial growth in the solid medium also followed the similar pattern as the maximum diameter $84.66 \mathrm{~mm}$ was at $\mathrm{pH} 6.5$, followed by $72.85 \mathrm{~mm}$ at $\mathrm{pH}$ 6.0. Here also lowest radial growth 38.60 $\mathrm{mm}$ was noted in case of culture having $8.0 \mathrm{pH}$.

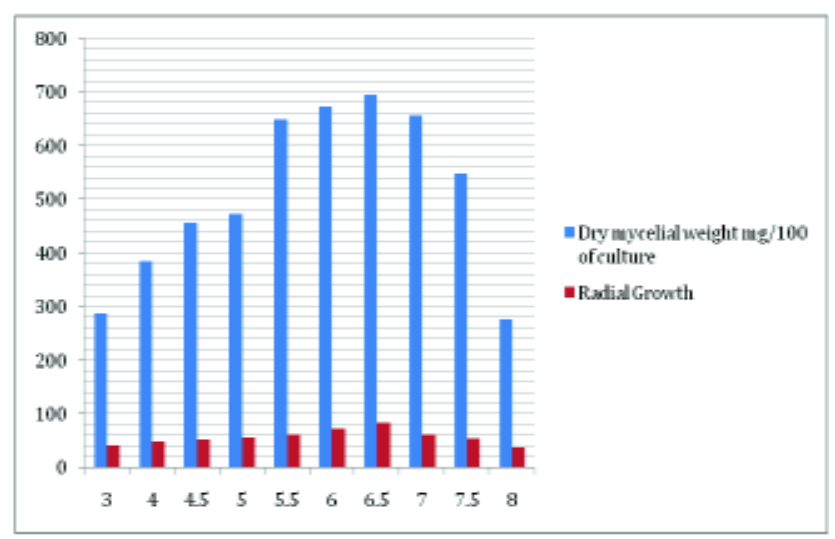

\section{Graph 1: Impact of different range of pH on mycelial growth of Alternaria alternata as indicated by dry mycelial weight and radial growth.}

The effect of different temperature levels viz., 16, $20,24,28,32,36$ and $40^{\circ} \mathrm{C}$ was studied to observe their impact on mycelial growth the results depicted in graph 2 revealed that fungus could grow at all the temperature levels as mentioned above. However, maximum dry mycelial weight $688.72 \mathrm{mg} / 100 \mathrm{ml}$ of culture and the maximum radial growth on Richard's solid medium was $78.48 \mathrm{~mm}$ at $28^{\circ} \mathrm{C}$. This was followed by dry mycelial weight at $34^{\circ} \mathrm{C}(626.28)$ and radial growth $68.34 \mathrm{~mm}$. Lowest dry mycelial weight $216.74 \mathrm{mg} / 100 \mathrm{ml}$ of culture 
and $34.42 \mathrm{mg}$ radial growth was obtained at $40^{\circ} \mathrm{C}$ at which the cultures were incubated.

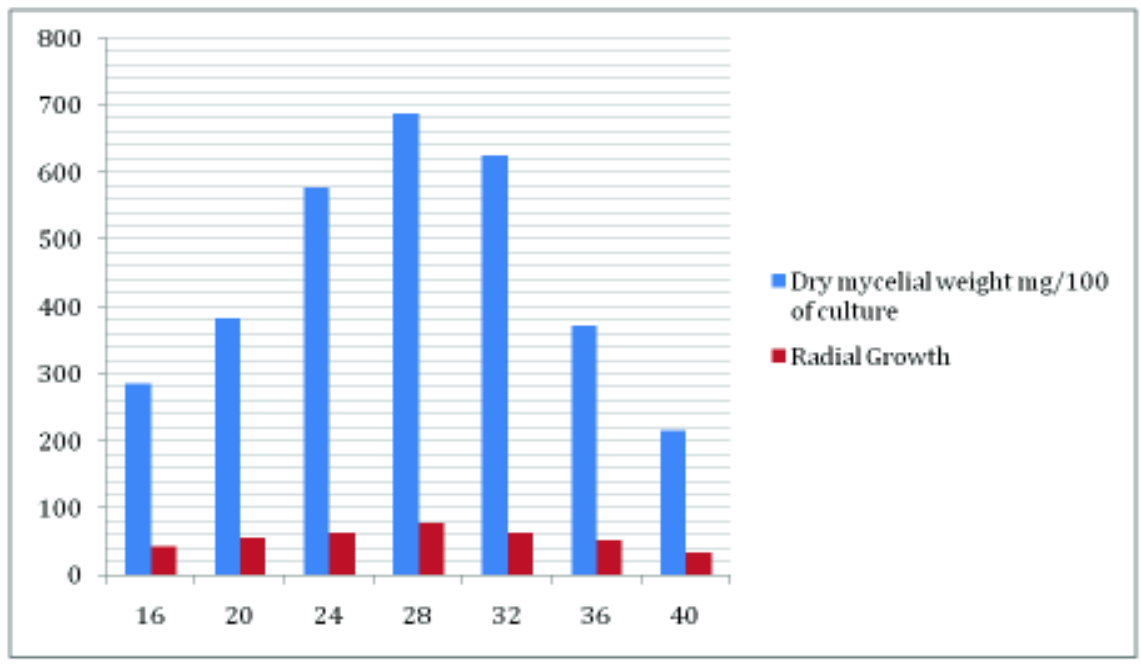

Graph 2: Impact of different temperature ranges on mycelial growth of Alternaria alternata as indicated by dry mycelial weight and radial growth.

\section{Carbon Source Utilization}

Culture characteristics viz., mycelial dry weight and radial growth of $A$. alternata were studied in vitro using nine carbon sources, where as sucrose was used as control. All sources of carbon tested exhibited growth of the test fungus but with different rate of growth. The results, graph 3 revealed that of the nine carbon sources tested, glucose was found most suitable that induced maximum dry mycelial weight $680.18 \mathrm{mg} / 100 \mathrm{ml}$ of culture and maximum radial growth $82.34 \mathrm{~mm}$.

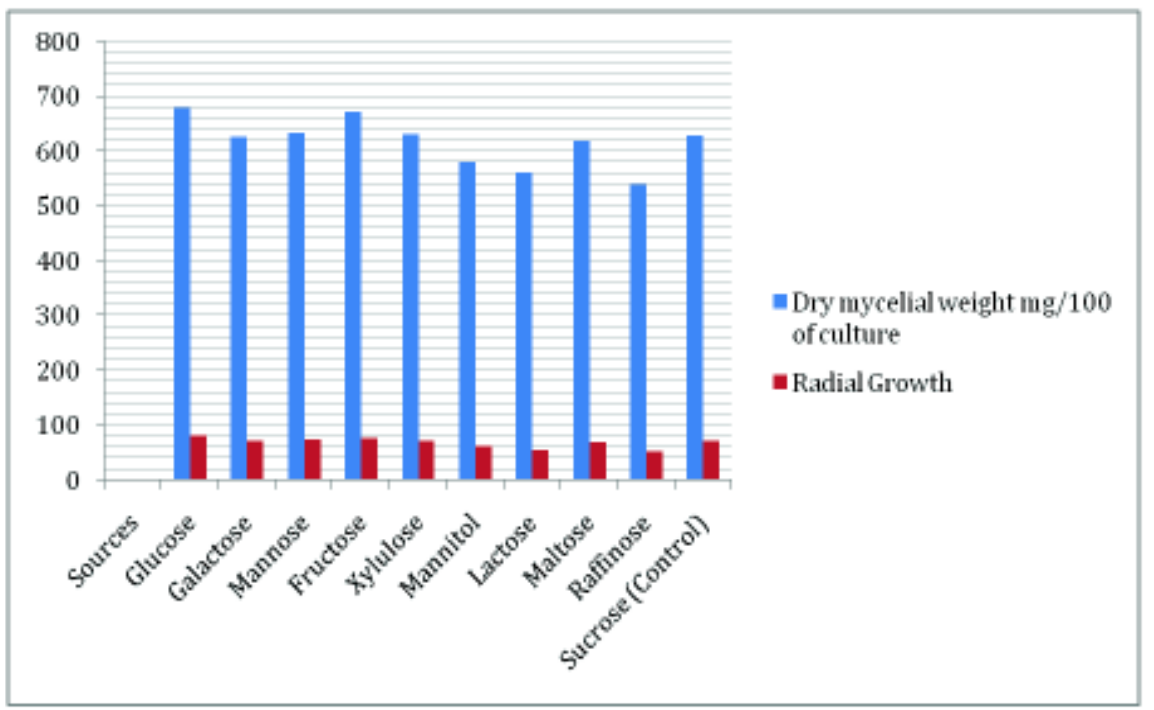

Graph 3: Impact of different Carbon Sources on mycelial growth of Alternaria alternata as indicated by dry mycelial weight and radial growth.

This was followed by fructose $672.84 \mathrm{mg} / 100 \mathrm{ml}$ of culture and $76.28 \mathrm{~mm}$ radial growth, and mannose $638.64 \mathrm{mg} / 100 \mathrm{ml}$ dry mycelial weight and $73.52 \mathrm{~mm}$ radial growth. Raffinose was found less suitable source of carbon where the dry mycelial weight was $540.28 \mathrm{mg} / 100$ $\mathrm{ml}$ of culture medium and $52.36 \mathrm{~mm}$ radial growth. 


\section{Effect of Nitrogen Sources}

Dry mycelial weights and radial growth of $A$. alternata were studied in vitro using six inorganic sources of nitrogen and eight organic sources of nitrogen. From the graph $4 \& 5$ it may be noted that all the sources of nitrogen induced growth of the test pathogen in vitro, however, there were difference in the quantum of the growth. Among the inorganic sources of nitrogen, potassium nitrate induced maximum mycelial growth, as is supported by the dry mycelial weight $678.24 \mathrm{mg} / 100 \mathrm{ml}$ of culture and the radial growth that is $78.15 \mathrm{~mm}$. This was followed by ammonium sulphate that was $670.84 \mathrm{mg} / 100 \mathrm{ml}$ of culture and 76.22 $\mathrm{mm}$ radial growth. Here aluminium nitrate was less suitable where dry mycelial weight was $538.18 \mathrm{mg}$ and the radial growth $60.72 \mathrm{~mm}$. Among the organic sources of nitrogen Alanine was most favourable as here the dry mycelial weight was $682.32 \mathrm{mg} / 100 \mathrm{ml}$ of culture and the radial growth was $82.38 \mathrm{~mm}$. This was followed by asparagines, $676.52 \mathrm{mg} / 100 \mathrm{ml}$ dry mycelial weight and $77.68 \mathrm{~mm}$ radial growth. This was followed by tryptophan $(672.12$ $\mathrm{mg} / 100 \mathrm{ml})$ and $(73.24 \mathrm{~mm})$ radial growth. Poor dry mycelial weight $(422.38 \mathrm{mg} / 100 \mathrm{ml})$ and $(46.28 \mathrm{~mm}$ radial growth) were noted in the medium containing $p$. amino benzoic acid as the source of nitrogen.

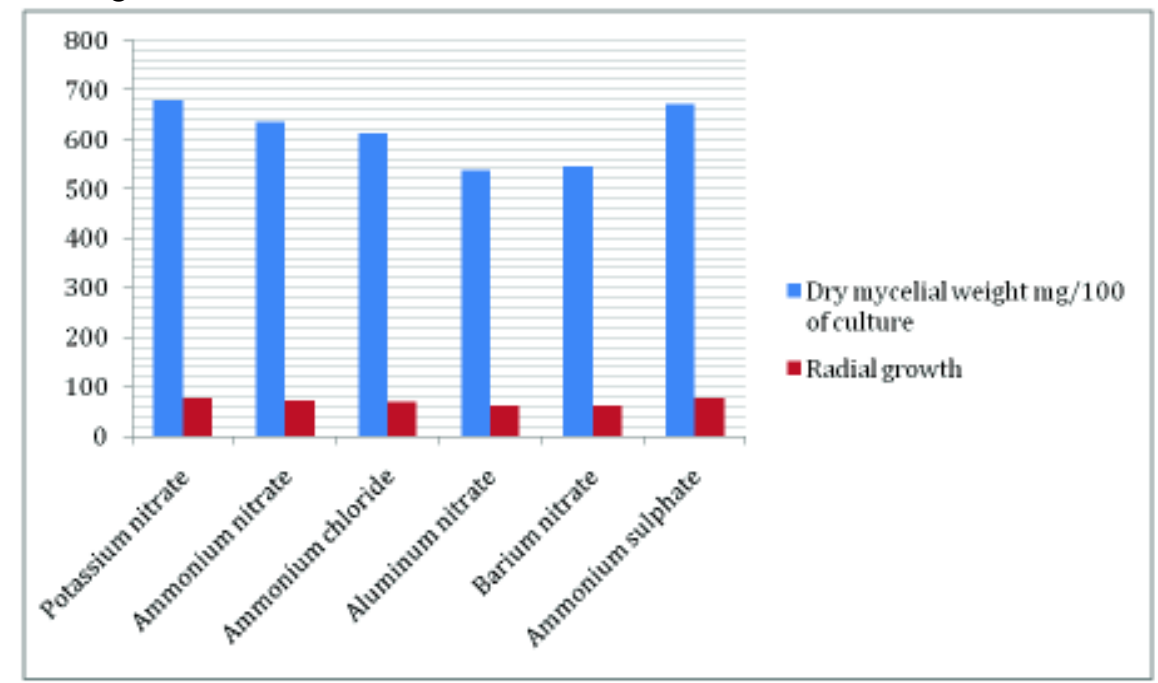

Graph 4: Impact of different Inorganic Nitrogen Sources on mycelial growth of Alternaria alternata as indicated by dry mycelial weight and radial growth.

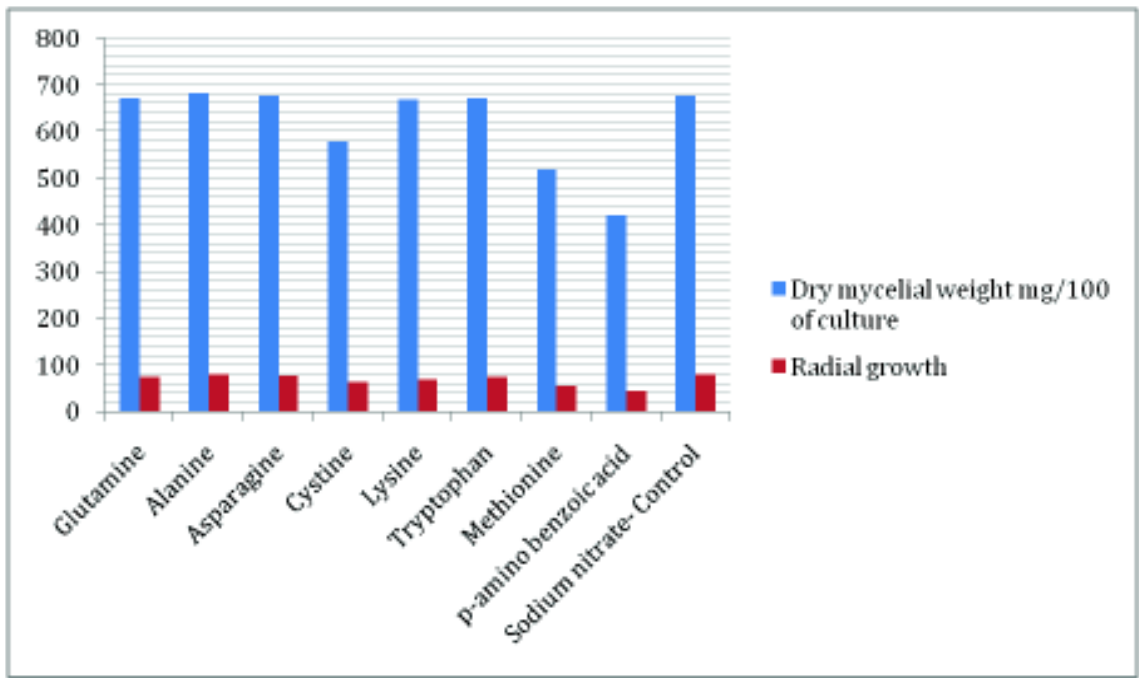

Graph 5: Impact of different Organic Nitrogen Sources on mycelial growth of Alternaria alternata as indicated by dry mycelial weight and radial growth. 


\section{PRAKASH AND PRASAD: EFFECT OF ENVIRONMENTAL FACTORS DIFFERENT FORMS OF CARBON....}

\section{DISCUSSION}

In the present study, effects of different ranges of $\mathrm{pH}$ and temperatures, different source so carbon and nitrogen were observed in vitro for mycelial growth of Alternaria alternata. Here it was observed that the pathogen could grow in different ranges of $\mathrm{pH}$ and temperatures but the quantum of growth rate was not equal. This clearly revealed that best $\mathrm{pH}$ for better growth was 6.5 , while the most suitable temperature was $28^{\circ} \mathrm{C}$. Present findings are in agreement with that of the findings of Sami and Hegedorn (1970) in case of Alternaria spp., Kumara and Rawal (2008) in Colletotrichum gloeosporioides; Hubballi et al., (2010) in Alternaria alternata, Deshmukh et al., (2012); in Colletotrichum gloeosporioides.

Devi et al., (2014) in Alternaria helianthi; Prasher et al., (2014) in Arthimium spp., Taware et al., (2014) in Alternaria carthami; and Chaudhary et al., (2017) in A. alternata.

In the present study, among the carbon sources, glucose was found most suitable for maximum mycelial growth of Alternaria alternata in vitro. Similarly, among the inorganic sources of nitrogen compound potassium nitrate promoted maximum mycelial growth while among the organic nitrogen sources alanine was most promising source of nitrogen with respect to mycelial growth of Alternaria alternata in vitro. Among the inorganic source of nitrogen Aluminium nitrate, and among the organic, pamino benzoic acid were the poor choice of the pest pathogen used in the present study. Present findings corroborate with the findings of Bais (1970); Goyal (1977); Bharti et al., (2007); Kumar et al., (2008); Thaware et al., (2010) in case of Alternaria alternata, Dange (2012); Bist (2013); Dhale et al., (2014); Itoo et al., (2014); Ectomycorrhizae, Hashan et al., (2015) in Aspergillus carbonaris; Koley \& Mahapatra (2015); Kushwaha (2015) Colletotrichum capsici, Shilpa et al., (2015); Fusarium sp and Sinha et al., (2015) in Alternaria solani.

\section{CONCLUSION}

Findings of the present work as well detailed literature survey, showed that fungal pathogens are capable to grow in diverse conditions of $\mathrm{pH}$, temperature, and carbon and nitrogen sources. Here it was observed that although the pathogen can grow in different range of $\mathrm{pH}$ and temperatures but the maximum growth was favoured at a particular $\mathrm{pH}$ and temperature. This was also true for the carbon and nitrogen sources also. Here also particular carbon and nitrogen induced maximum growth, than others inspite of the facts that all conditions \& the pathogen was similar. This reveals adaptive capability of the pathogen for their survival in nature.

\section{ACKNOWLEDGMENT}

The authors are thankful to the Head, Department of Botany, B.R.A. Bihar University, for his kind permission to avail the Laboratory and Library facilities of the Department.

\section{REFERENCES}

Bahle U.N., 2010. Effect of nutritional sources on fungicide resistant and sensitive Fusarium oxysporum f.sp. Spinaciae inciting wilt of spinach Spinacea oleracea L., Bio. Sci. Biotech. Res. Comm., 3(2): 169-173.

Bais B.S., Singh S.B. and Singh D.V., 1970. Effect of different carbon and nitrogen compounds on growth and sporulation of Curvullaria pallescens. Indian Phytopath., 23: 511-517.

Bharti T., Kulkarni J.H., Krishnaraj P.U. and Algawadi A.R., 2007. Effect of different carbon sources on the biomass of Metarhizium anisopliae. Karnatka J. Agric. Sci., 20: 310-311.

Bist S., 2013. Growth responses of aquatic hyphomycetes to different sources of carbon and nitrogen. J. App. And Nat. Sci., 5: 313-317.

Dange V.S., 2012. Effect of nitrogen sources on the growth of different species of Curvularia, Fusarium,Phoma and Botryodiplodia. Journal of Experimental Sciences, 3: 24-27.

Devi P.A., Mohan S., Kaleshwari N. and Maharaja N., 2014. Physiological and nutritional requirements for the determination of Alternaria helianthi in sunflower. W.J. of Agricultural Sciences, 2(4): 4752.

Dhal A., Beura S.K., Palai S.K. and Khamari B., 2014. Effect of different carbon and nitrogen sources on mycelial growth of Alternaria solani, the instant of early blight disease of tomato. Journal of Plant Protection and Environment, 11(2): 91-94. 
PRAKASH AND PRASAD: EFFECT OF ENVIRONMENTAL FACTORS DIFFERENT FORMS OF CARBON....

Gawai D.U. and Mangnalikar S.S., 2018. Effect of temperature and $\mathrm{pH}$ on growth of Atlernaria alternata, leaf spot pathogen of Soybean. Bioscience Discovery, 9(1): 162-165.

Gomawat P.D. and Ghos S.K., 1980. Studies on the physiology of growth of Alternaria solani. Ind. J. of Mycology and Plant Pathology, 7: 155-157.

Goyal K.N., 1977. Effect of $\mathrm{pH}$, carbon and nitrogen nutrition on the growth and sporulation of Alternaria teneis. Indian J. Mycol. Pl. Pathol., 7(2): 155-157.

Hashem A., Abd-Allah E.F., Al-Obeed R.S., Aziz A., Algarawi A. and Alwanthani H.A, 2015. Effect of carbon, nitrogen sources and water activity on growth and Ochratoxin production of Aspergillus carbonarius (Bainier) Thom. J. J. Microbiol., 8(2): $1-8$.

Hasija S.K., 1970. Physiological studies of $A$. Citri \& A. tenius. Mycologia, 63: 289-295.

Hasiza S.K., 1970. Physiological studies of Curvularia pallescens. Nova Hedwigia, 19: 551-558.

Hubballi M., Nakkeeran S., Raghuchander T., Anand T. and Ramasamy S., 2010. Effect of environmental conditions on growth of Alternaria alternata causing leaf blight of noni. World J. of Agricultural Sciences, 6(2): 171-177.

Itoo Z. Ahmad and Reshi Z.A., 2014. Effect of different nitrogen and carbon sources and concentrations on mycelial growth of Ectomycorrhizae fungi under in vitro condition. Scandinavian J. of Forest Res., 1: $1-10$.

Koley S. and Mahapatra S.S., 2015. Evaluation of culture media for growth characteristic of Alternaria solani causing early blight of tomato. J. Plant Pathology \& Microbiology, 10: 1-5.

Kumar K.L., Wasantha and Rawal R.D., 2008. Influence of carbon, nitrogen, temperature and $\mathrm{pH}$ on the growth and sporulation of some Indian isolates of Colletotrichum gloeosporioides causing anthracnose of papaya. Tropical Agri. Res. and Extension, 11: 7-12.
Lilly V.G. and Barnett H.L., 1951. Physiology of fungi. Mc Graw Hill Book Co. Inc. New York, Toronto and London.

Mathur S.B. and Sarboy A.K., 1977. Physiological studies on Alternaria alternata from sugar beet. Indian J. of Phytopathology, 30: 432.434.

Mehta J., Jakhetia M., Chaudhary S., Mirza J., Sharma D., Khatri P., Gupta P. and Nair M.M., 2012. Impact of carbon and nitrogen sources on the Trichoderma viride and Beauveria bassiana. Euro. J. Exp. Biol., 2: 2066-2067.

Mishra P.T. and Mishra V., 2012. Effect of media, temperature and $\mathrm{pH}$ on growth of Atlernaria alternata causing leaf spot of cotton. Annals of Plant Protection Sci., 20: 246-247.

Mohapatra A., Mohanty A.K. and Mohanty N.N., 1977. Studies on physiology of the sesame leaf blight pathogen, Alternaria sesame. Indian Phytopathology, 30: 332-334.

Parathibha V.H., Nanje Gowda and Nagaraju D., 2008. Effect of temperature, and $\mathrm{pH}$ on growth of different isolates of Alternaria helianthi on sunflower. Mysore J. Agric. Sci., 42: 139-142.

Pose G., Patriarca A., Kyanko V., Pardo A. and Pinto V.F., 2009. Effect of water activity and temperature on growth of Alternaria alternata on a synthetic tomato medium. Int. J. of Food. Microbiology, 135: $60-63$.

Prasher B., Chauhan R. and Singh A., 2014. Effect of physical and nutritional factors on the growth and sporulation of Arthrinum phaeospormum (Corda) M.B. Ellis. J. of Advanced Bot. and Zoology, 1(4): $1-6$.

Rawla G.S. and Tondon S.K., 1977. Nutritional requirements of fungi-I, Influence of different carbon compounds on the growth of Nigrospora oryzae. Indian Journal of Mycology \& Plant Pathology, 7: 72-73.

Reddy S.M., 1971. Nitrogen requirements of five species of Helminthosporium. Proc. Ind. Acad. Sci. India, 54: 142-146. 
PRAKASH AND PRASAD: EFFECT OF ENVIRONMENTAL FACTORS DIFFERENT FORMS OF CARBON....

Shilpa P., Rao V.K., Rao K.N., Grisham S. and Reddy S.M., 2015. Influence of carbon and nitrogen source on growth, DON and NIV production by two species of Fusarium isolates form Finger millets. Int. J. Pharm. Science, 7(3): 136-139.

Sinha A., Ara A., Kumar A. and Alam A., 2015. Study on effect of different carbon and nitrogen sources on growth and sporulation of Alternaria solani. International Journal for Exchange of Knowledge, 2(2): 10-15.
Thware D.S., Fugro P.A., Kadam J.J., Kanse R.V. and Rite S.C., 2010. Effect of different carbon and nitrogen sources on the growth and sporulation of Alternaria alternata (Fr.) Keillser causing leaf blight of Cowpea. Int. Journal of Plant Protection, 3(2): 353-355.

Verma V., 1970. Effect of temperature and hydrogen ion concentration on three pathogenic fungi. Sydowia, 23: $164-168$. 